\title{
CLAYTON ACT, SECTION 5: AID TO TREBLE DAMAGE SUITORS?*
}

Private parties may recover treble damages for injuries caused by violations of the antitrust laws. ${ }^{1}$ Although intended to provide a principal means of policing industry and enforcing antitrust laws, ${ }^{2}$ private litigants, despite possible triple recovery, initially were reluctant to bring these suits. ${ }^{3}$ To

*Emich Mfotors Corp. v. General Miotors Corp., 340 U.S. 558 (1951).

1. $\$ 4$ of the Clayton Act reads in part: "Any person who shall be injured in his business or property by reason of anything forbidden in the antitrust laws may sue therefor in any district court of the United States ... and shall recover threefold the damages by him sustained and the cost of suit, including a reasonable attorney's fee." 33 STAr. 731 (1914), 15 U.S.C. $\$ 15$ (1946), superseding similar provisions in the Sherman Aet, 26 Stat. 210 (1890) and 28 Stat. 570 (1S94).

Injuries arising from violations of the Sherman Act, 26 ST.1r. 209 (1890), 15 U.SC. $\$ 1, \S 2$ (1946), the Clayton Act, 38 Stix. 730 (1914), 15 U.S.C. $\$ 12-\$ 14$ (1946) and both the civil and criminal provisions of the Robinson-Patman Act, 49 STAr. 1520 (1936), 15 U.S.C. $\$ 13$ (1946) fall within the provisions of this section. For recent full survey of Robinson-Patman treble damage cases, see Rowe, Price Discrimination, Comsctition, and Confusion; Another Look at Robinson-Patman, 60 YALE L. J. 929, 940 n. 65, 941 n. 73, 958 n. 198, 961 n. 210 (1951).

Incorporated cities, Chattanooga Foundry Works v. Atlanta, 203 U.S. 390 (1906), and states, State of Georgia v. Evans, 316 U.S. 159 (1942), but not the United States, United States v. Cooper, 312 U.S. 600 (1940), are "persons" within the meaning of Section 4 and can sue for treble damages. Proposed amendments allow the United States to recover treble damages, H.R. 109, 82d Cong., 1st Sess. (1951), or only actual damages, H.R. 3408, 82d Cong., 1st Sess. (1951).

The treble damage trial judge determines a "reasonable attorney's fee" within his discretion on the basis of character of services rendered, amount of time consumed and result achieved. See, e.g., Connecticut Importing Co. v. Frankfort Distilleries, 101 F. 2d 79, 81 (2d Cir. 1939). But cf. Milwaukee Towne Corp. v. Loew's, Inc., 190 F. $2 d$ 561 (7th Cir. 1951), where, on appeal, attorney's fees were reduced from $\$ 225,000$ to $\$ 75,000$. Commenting on the "delicate and embarrassing" matter, the court noted that the "fabulous amount allowed" would "equal the total annual salary received by all members of the Supreme Court." Id. at 569-70. Since trial courts cannot take into account the possibilty of appeal, appellate courts may add additional attorney's fees. American Can Co. v. Ladoga Canning Co., 44 F.2d 763 (7th Cir. 1930), corl. denicd, $2 \$ 2$ U.S. $\$ 99$ (1930).

2. See Hanilton \& Tw, Antitrust in Action 5-10 (TNEC Monograph 16, 1940) ; Testimony of Walton Hamilton, Hearings before the Subcommittec on Study of Monopoly Pozer of the Committee on the Judiciary on H.R. 7905, 81st Cong., 2d Sess., Pt. 5,56 (1950). For conflicting views on the need and efficacy of private suit, see 21 Cong. ReC. 1768 (1890); id. at 2569.

3. In the first fifty years of Sherman Act enforcement only 175 reported suits were brought. Only 13 suitors were awarded judgments, totaling $\$ 1,270,000$. Eleven other judgments for $\$ 12,756,000$ were overruled by appellate courts. Comment, is U. oF Crr. L. Rev. 130, 138 (1950). These figures do nut include out-of-court settlements. The suits were few in comparison with the number of businessmen probably injured by antitrust violations in this period.

Since 1940 , there has been an acceleration in both government antitrust enforcement and private suits. 
prevail they had to prove three difficult elements: (1) defendant's violation of antitrust law ; $;^{4}$ (2) causal connection between that violation and plaintiff's injury $;^{5}$ and (3) amount of resultant damages. ${ }^{6}$ And courts, impressed by

\begin{tabular}{lrrrrrrrrrr}
\hline & \multicolumn{8}{c}{ Antitrust cases (filed is U.S. district courts) } \\
& 1941 & 1942 & 1943 & 1944 & 1945 & 1946 & 1947 & 1948 & 1949 & 1950 \\
Government Cases & & & & & & & & & & \\
$\quad$ Civil & 28 & 35 & 24 & 12 & 20 & 18 & 33 & 19 & 39 & 42 \\
$\quad$ Criminal & & & 40 & 13 & 9 & 15 & 11 & 18 & 27 & 34 \\
Private Civil Cases & 110 & 70 & 40 & 50 & 27 & 68 & 64 & 78 & 162 & 157
\end{tabular}

ANNuAL Report of the Director of the Administrative Office of tHe UNited States Courts 1950113 (transmitted to the Judicial Conference of the United States, Sept. 8, 1950). These data, however, indicate the number of suits filed in district courts, while the pre1940 data only refer to cases actually reported.

4. Proof of an antitrust violation is difficult, since the violation is often based on a tacit agreement consisting of complex terms. E.g. FTC v. Cement Institute, 333 U.S. 683,687 (1948) (100,000 page record compiled in three years of FTC hearings on basing point system). Recognizing these difficulties, courts allow proof of conspiracy by inferential proof. E.g. Milgram v. Loew's Inc., 192 F.2d 579 (3d Cir. 1951) (conspiracy inferred from conscious parallel business practices). "[In] this modern era of increasing subtletics, it is rare indeed for a conspiracy to be proved by direct evidence." Id. at 583. However, private litigants must prove defendant's antitrust violation without evidence compiled by a grand jury and without the investigatory facilities available to the government. See Hamilton \& Till, Antitrust in Action 83 (TNEC Monograph 16, 1940).

5. This is usually difficult to show because the injury may in part have been caused by other factors which influence the plaintiff's business fortunes, such as obsolete equipment, economic recession or poor management. See Haniluon \& Tilu, ANTitrust IN Action 84 (TNEC Monograph 16, 1940). Moreover, courts often demand certainty of proof for establishing the "fact" of damage. E.g. Locker v. American Tobacco Co., 218 Fed. 447 (2d Cir. 1914). However, the Supreme Court recently relaxed these proof requirements, holding that a jury might conclude "from the proof of defendants' wrongful acts and their tendency to injure plaintiffs' business, and from the evidence of the decline in prices, profits and values, not shozen to be attributable to other canses, that the defendants' wrongful act had caused damage to the plaintiffs." Bigelow v. R.K.O. Radio Pictures, 327 U.S. 251, 264 (1946) (emphasis added). Cf. Milwaukee Towne Corp. v. Loew's Inc., 190 F.2d 561 (7th Cir. 1951), cert. denied, 20 U.S.L. WEEK 3179 (1952) ("fact" of damages not found where injury arose from alleged refusal of motion picture produccr to license first run pictures because evidence insufficient to show that plaintiff requested such pictures).

6. Proof of damages has been a major obstacle to treble damage recoveries. The plaintiff usually bases his damage claim on either increased costs, Thomson v. Cayser, 243 U.S. 66 (1917), or on lost profits, Story Parchment Co. v. Paterson Parchment Paper Co., 282 U.S. 555 (1931). The lost profits method of computing damnages necessarily involves conjectural proof as to the amount of the plaintiff's profits if the defendant's illegal activity had not interfered. However, the Supreme Court recently held inferential proof acceptable where none better was available. "[T] he wrongdoer may" not object to the plaintiff's reasonable estimate of the cause of injury and of its amount, supported by evidence, because not based on more accurate data which the wrongdoer's misconduct has rendered unavailable." Bigelow v R.K.O. Pictures, Inc., 327 U.S. 251, $265 \cdot(1946)$ reversing, 150 F.2d 877 (7th Cir. 1945) (damages based on plaintiff's lost profits shown by (1) a comparison between profits prior to the restraint with probable, subsequent profits, and (2) a comparison of actual profits during the period of restraint 
the severity of threefold damages, ${ }^{7}$ held plaintiffs to high standards of proof. ${ }^{8}$ Moreover, private litigants were often unwilling to take the financial gamble ${ }^{9}$ involved in protracted litigation ${ }^{10}$ with wealthy corporate defendants.

To encourage treble damage suits by reducing the plaintiff's required proof - and litigation expenses, Congress enacted Section 5 of the Clayton Act.11

with those of comparable competing theatres of defendants); noted 41 ILL L. REv. 462 (1946). See Milwaukee Towne Corp. v. Loew's Inc., 190 F.2d 561 (7th Cir. 1951). Noting reversal of its holding in Bigelow case, supra, that proof of damages was too speculative, the Seventh Circuit states that the Supreme Court "leaves little room for defendants' attack upon the court's damage findings, providing, of course, the fact of damage is shown." Id. at 566 .

For impact of liberalized rules for proving damages on treble damage suits sce MicConnell, The Treble Damage Actiost, U. of IrI. L. Forosi 659, 664 (1950); Comment, 18 U. of CHI. L. REv. 130, 133, 138 (1950).

7. "The right which the said Acts (i.e. the Sherman and Clayton Acts) give to a person to recover three-fold the damages he has sustained, is an unusual one, the remedy is drastic, and the Acts are to be strictly construed ..." Westor Theatres, Inc. v. Warner Bros. Pictures, 41 F. Supp. 757, 762, (D.N.J. 1941). Whether or not damages are punitive or compensatory is disputed. See Vold, Are Threefold Danoges Under the Anti-Trust Act Penal or Compensafory, $28 \mathrm{Kr}$. L.J. 117 (1940).

8. See McConnell, stpra note 6, at 661,663 (1950).

9. A principal obstacle to treble damage suits is the extreme cost of litigation. Pre-trial preparation demands research by highly-skilled attorneys; the trial is long, susceptible to delay and procrastination; appeals and new trials are endless. Thus, corporate offenders, possessed of vast resources, are often able to exhaust their opponents. For discussion of costs, see Hearings on H.R. 7905, stipra note 2, pt. 5, 3 (19:0); Hanimton \& THL, ANTTtrust in Action 83 (TNEC Monograph 16, 1940); Danicl, Einforcement of the Sherntan Act by Actions for Treble Damages, 34 VA. L. Rew, 901, 923 (1948).

"I tell them [prospective suitors] that if they do not have $\$ 25,000$ for the taling of depositions under the Federal rules, at least $\$ 25,000$ just for costs and transcripts and traveling expenses, that they had better drop the suit ... The methods by which a plaintiff can be worn out ... Witnesses are supposed to show up at 10 o'clocls, and they do not show up until 11. You ask them a few questions, and it is the wrong officer of the company. . . . Then perhaps if things get too bad then you can go into court and get the court to make an order against that lind of tactics. So there are long arguments on that ..." Testimony of Thurman Arnold, Hcarisgs before a Subcommittee of the Committee on the Judiciary on S. 1910, 81st Cong., 1st Sess., 3 (1949).

10. The median length of time from filing to disposition of treble damages suits was twice that of all civil cases tried; the median length of trials was five times that of all cases tried. Annuar REPors, supra note 3, at 114. See, e.g., the Bausch Machine Tool Company's attempt to recover damages against the Aluminum Company of America. The litigation continued for 16 years and included "the filing of two suits which were never tried, two jury trials . . . a bill of discovery, three appeals and two petitions for certiorari (both denied) at an expense of hundreds of thousands of dollars." Note, 37 CoL. L. Rev. 269, 288 (1937).

11. Section 5 provides: "A final judgment or decree hereafter rendered in any civil or criminal prosecution or in any suit in equity brought by or on behalf of the United States under the antitrust laws to the effect that a defendant has violated said laws shall be prima facie evidence against such defendant in any suit or proeceding brought by any 
This permits treble damage plaintiffs to introduce final ${ }^{12}$ criminal judgments and equity decrees rendered against defendants in antitrust actions brought by the government ${ }^{13}$ as prima facie ${ }^{14}$ evidence of all matters determined and essential to the prior adjudication. ${ }^{15}$ Section 5 , until recently, has been

other party against such defendant under said laws as to matters respecting which said judgment would be an estoppel as between the parties thereto: Provided, this section shall not apply to consent judgments or decrees entered before any testimony has been taken." 38 StAT. 731 (1914), 15 U.S.C. 16 (1946).

This section was enacted in response to a message by President Wilson. "I hope we shall agree in giving private individuals . . . the right to found their suits for redress upon facts and judgments proved and entered in suits by the Government. . . . It is not fair that private litigants should be obliged to set up and establish again the facts which the Government has proved. He can not afford, he has not the power, to make use of such processes of inquiry as the Government has command of . ." 51 ConG. Rec. 1962, 1964 (1914).

12. A "final judgment or decree" within the meaning of $\S 5$, supra note 11 , refers to a "final disposition of the case, i.e., a final judgment by reason of failure to appeal within the statutory period, or a final judgment by reason of an affirmance of the appeal by the court of last resort." Twin Ports Oil Co. v. Pure Oil Co., 26 F. Supp. 366, 369 (D. Minn. 1939), aff'd, 119 F.2d 747 (8th Cir. 1941), cert. denied, 314 U.S. 644 (1941). See cases cited in note 16 infra where judgments and decrees held inadmissible under \& 5 because of lack of "finality."

13. These judgments and decrees had been unavailable to a private suitor. Butckye Powder Co. v. DuPont Powder Co., 248 U.S. 55 (1918) (judgment rendered prior to passage of $\$ 5$ inadmissable as evidence in treble damage suit). For general discussion of admissibility of judgments as evidence in another cause of action see 4 WIGMore, EvidENCE $\S \S 1346,1346 \mathrm{a}$ (3d ed. 1940); 5 id. §1671a.

14. I.e., sufficient, standing alone and uncontroverted, to sustain a judgment on the issues for which it is submitted. But the evidence loses its prima facie qualities in the face of countervailing evidence. Thus, it does not shift the burden of proof but mercly compels the defendant to come forward with evidence. "Being prima facie evidence, the judgment is not conclusive in this case. It is merely sufficient evidence of a violation by these defendants of the anti-trust laws to put these defendants to their proof." Charge to the jury, quoted in Emich Motors Corp. v. General Motors Corp., 181 F. 2d 70, 76 (7th Cir. 1950), rev'd on other grounds, 340 U.S. 558 (1951). Once the defendant comes forward with evidence, as he invariably does, the burden of going forward shifts back to the plaintiff. Hearings on H.R. 7905, stipra note 2, pt. 5, p. 12 (1950).

"In general the courts have looked upon suits for triple damages with such disfavor that the statutory presumption in favor of the plaintiff is rather lightly entertained and the rebuttal rather generally indulged. The provision is quickly swallowed up in the rules of evidence and presently there is little to distinguish the trial from others of its kind." Hanimton \& Till, Antrtrust in Action, 83 (TNEC Monograph 16, 1940). See also note 33 infra.

15. The statute, supra note 11, simply mentions "estoppel" which could connote res judicata as well as collateral estoppel. Res judicata would apply not only to matters litigated and determined, but to any other admissible matter which might have been offered to sustain the judgment; while collateral estoppel applies only to matters actually litigated and essential to sustain the judgment. For a comparison of res judicata and collateral estoppel, see Scott, Collateral Estoppel by Judgment, 56 Harv. L. Rev. 1 (1942) ; Restatestent, Judganents $\$ \$ 68,69,70$ (1942); Cromwell v. County of Sac, 94 U.S. 351, 353 (1876).

Although the Congressional debates on the Clayton Act do not distinguish between 
applied only in private suits following successful equity proceedings by the government for Sherman Act violations. ${ }^{10}$ Since specific findings of fact accompany equity decrees, the issues determined in these proceedings are apparent. Therefore, the trial judge in the treble damage suit under Section

the two types of estoppel, Congress probably was thinling in terms of collateral estoppel, since it assumed that the judgment was to be evidence of the "facts determined" rather than of the facts that might have been determined. See statement of Senator Walsh, 51 CoNG. ReC. 13851 (1914).

The courts have never specifically defined "estoppel" in $\$ 5$, although in one case it was assumed in dicta that this term referred to "estoppel by judgment" (collateral estoppel). Fifth and Walnut Inc v. Loew's Inc. 176 F.2d 587, 593, (2d Cir. 1949), cert. denied, 338 U.S. $\$ 94$ (1949). In the few cases where $\$ 5$ has been applied it has been treated as connoting collateral estoppel. E.g. Emich Motors Corp. v. General MIotors Corp., 340 U.S. 558 (1951). "Such estoppel extends only to questions 'distinetly put in issue and directly determined' in the criminal prosecution. . . In the case of a criminal conviction based on a jury verdict of guilty, issues which were essestial to the verdict must be regarded as having been determined by the judgment. . . Accordingly, we think plaintiffs are entitled to introduce the prior judgment to establish prima facie all matters of fact and law necessarily decided by the conviction and the verdict on which it was based." (Emphasis added.) Id. at 569.

16. Equity decrees were admitted under $\$ 5$ in the following cases. Eastman Kodal: Co. v. Southern Photo Materials Co., 295 Fed. 98 (5th Cir. 1923), off'd, 273 U.S. 359 (1927) ; Rankin Co. v. Associated Bill Posters, 42 F.2d 152 (2d Cir. 1930), ecrt. dericd, 282 U.S. 864 (1930) ; Turner Glass Corp. v. Hartford Empire Co., 173 F. $2 d 49$ (7th Cir. 1949) ; DeLuxe Theatre Corp. v. Balaban \& Katz, 95 F. Supp. 983 (N.D. Ill. 1951); Fanchon \& Marco v. Paramount Pictures, Inc, 100 F. Supp. 84 (S.D. Cal. 1951). See also Sinaiko Bros. Coal \& Oil Co. v. Ethyl Gasoline Corp., 2 F.R.D. 305 (S.D. N.Y. 1942) (proper for plaintiff to plead decree); H. E. Miller Oil Co. v. Socony-Vacuum Oil Co., 37 F. Supp. 831 (D. Mo. 1941) (same). But if. Mlilgram v. Loew's Ine., 192 F.2d 579 (3d Cir. 1951), affirming 94 F. Supp. 416 (E. D. Pa. 1950). Although the District Court apparently excluded the decree rendered in United States v. Paramount Pictures, Inc. 66 F. Supp. 323 (S.D. N.Y. 1946), 192 F.2d 579, 593 n. 5. the Third Circuit took judicial notice of decree as background material. "[T] he past proclivity of these defendants to unlawful conduct may be of some significance here, where the conspiracy alleged by plaintiff is identical in scope and nature to one of the conspiracies found in the Paramount case. . Viewing the facts of this case in the light of the specific finding in the Paramosnt case, the inference of conspiracy here is strengthened." Id. at 584. In a vigorous dissent Judge Hastie, noting the "narrow and precisely defined authorization to use a judgment or decree" rendered in a public antitrust suit under $\$ 5$, concludes, "This statute would have been unnecessary if, without legislation, courts were authorized to make the present far brosder use of prior wrongdoing. . . To imply new wrongdoing from past wrongdoing is in itself alien to our conception of fair trial. To do so without even the introduction of trial evidence and opportunity to rebut it is doubly wrong." Id. at 594-5. See also Dipson Theatres, Inc. v. Buffalo Theatres, Inc, 190 F.2d 951, 958 (2d Cir. 1951).

Equity decrees were not admitted under $\$ 5$ in the following cases. Brunswick-Ball:eCollender Co. v. American Bowling \& Billiard Corp., 150 F. 2d 69 (2d Cir. 1945), cert. denied, 326 U.S. 757 (1945) (FTC order, upon which Circuit Court had not entered enforcing decree, not a "final decree" under \$ 5); Proper v. John Bene \&. Sons, 295 Fed. 729 (E.D. N.Y. 1923) (same; FTC proceeding not instituted "under antitrust laws"); Fifth \& Walnut, Inc v. Loew's, Inc., 176 F.2d 5S7 (2d Cir. 1949), cert. denicd, 338 U.S. 894 (1949) (decree, remanded in part, not a "final decree"); Duluth Theatre Corp. v. Paramount Pictures, Inc., 72 F. Supp. 625 (D. Minn. 1947) (decree, pending on appeal, not a "final decree"); Alden-Rochelle, Inc. Y. American Society of Composers, 
5 simply admits the decree as prima facie evidence of these matters. ${ }^{17}$ But criminal judgments, unlike equity decrees, contain no findings of fact; they are usually bare statements of guilt based on general jury verdicts. Thus, when Section 5 is invoked in a treble damage suit following a successful criminal antitrust prosecution, courts must look deeper to decide what issues were previously determined.

In Emich Motors Corp. v. General Motors Corp. ${ }^{18}$ the Supreme Court in determining the evidentiary effect of a prior criminal antitrust judgment had to interpret Section 5 for the first time. Emich, an automobile dealer sued General Motors and General Motors Acceptance Corporation, a whollyowned financing subsidiary, for treble damages, alleging cancellation of his GM franchise pursuant to a conspiracy in violation of the Sherman Act. An earlier criminal judgment had found GM and GMAC guilty of a conspiracy to restrain unduly interstate trade and commerce for the purpose of monopolizing the financing of GM cars by compelling dealers to use the credit facilities of GMAC.19 The indictment had charged a number of coercive acts, including cancellation of non-compliant dealers' franchises, as means of effectunting the conspiracy. A jury, apparently instructed to find conspiracy only if some coercive acts were proved, ${ }^{20}$ had returned a general verdict of guilty. In the

Authors \& Publishers, 3 F.R.D. 157 (S.D. N.Y. 1942) (consent decree); Ulrich v. Ethyl Gasoline Corp., 2 F.R.D. 357 (W.D. Ky. 1942) (decree, although not consent decree under $\S 5$, rendered on stipulated facts solely for purposes of equity suit); Buckeye Powder Co. v. DuPont Powder Co., 248 U.S. 55 (1918) (decree rendered prior to enactment of $\S 5$ ) ; Volk v. Paramount Pictures, Inc., 91 F. Supp. 902 (D. Minn. 1950) (action under Declaratory Judgments Act not an "action" arising under antitrust laws).

Criminal judgments were not admitted under $\$ 5$ in the following cases. Twin Ports Oil Co. v. Pure Oil Co., 26 F. Supp. 366 (D. Minn. 1939), aff'd, 119 F. $2 d 747$ (8th Cir 1941), cert. denied, 314 U.S. 644 (1941) (judgment, based on plea of nolo contendere, "consent judgment" under Section 5; judgment, pending on appeal, not "final judgment") ; Barnsdall Refining Corp. v. Birnamwood Oil Co., 32 F. Supp. 308 (E.D. Wis. 1940) (plea of nolo contendere); Alden-Rochelle, Inc.v. American Society of Composers, Authors \& Publishers, supra, (same); A. B. Dick Co. v. Marr, CCH TRAdE REG. REP. '48-'51 DEC. \& 62,762 (S.D. N.Y. 1950) (same).

17. E.g. Rankin Co. v. Associated Bill Posters, 42 F. 2d 152 (2d Cir. 1930).

18. 340 U. S. 558 (1951).

19. United States v. General Motors Corp., 121 F.2d 376 (7th Cir. 1941), ccrt. denied, 314 U.S. 618 (1941).

20. The trial judge instructed the jury, "The ultimate question, after all, is whether, under all the facts and circumstances the acts of coercion mentioned in the indictment ... have been proved beyond a reasonable doubt ...." quoted in United States v. Gencral Motors Corp., 121 F.2d 376, 385 (7th Cir. 1941). In affirming, the Seventh Circuit stated, "We do not hesitate to hold that the jury findings of conspiracy and cocrcion" are supported by the evidence." Id. at 398 (emphasis added). But cf. id at 405: "[I]t was not necessary for the government to show that a single dealer had in fact been discriminated against or coerced." "[I]t was unnecessary for the Government to prove the performance of any of the acts or means, except for the purpose of establishing venue, in order for the jury in the criminal proceeding to find defendants guilty." Emich Motors Corp. v. General Motors Corp., 181 F.2d 70, 76 (7th Cir. 1950), revid, 340 U.S. 558 (1951). 
treble damage suit, Emich introduced the criminal judgment as prima facie evidence of the defendants' cancellation of his franchise pursuant to the conspiracy. The Seventh Circuit, reversing the trial court partly because of its submission of the criminal indictment to the jury, ${ }^{21}$ considered the

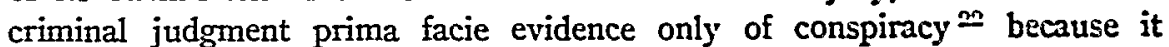
read the verdict as not necessarily establishing particular coercive acts. ${ }^{23}$ The Supreme Court reversed. In its view, the criminal judgment was "firmly rooted in a finding of coercive conduct." 24 Thus it was prima facie evidence not only of conspiracy, but also of its effectuation by GMI's coercion of its dealers. ${ }^{25}$ Moreover, the Supreme Court directed trial judges to go beyond the bare judgment of guilt and determine ${ }^{20}$ the issues decided in the criminal case.

The Emich decision defines Section 5's utility to private suitors. Trial courts, instructed to go behind the prior criminal judgment, may construe it as prima facie evidence of a treble damage defendant's illegal conspiracy and also of other litigated issues essential to the judgment. Since in most criminal antitrust proceedings both a combination to violate the Sherman

21. Emich Motors Corp. v. General MLotors Corp., 181 F.2d 70 (7th Cir. 1950), rev'd, 340 U.S. 558 (1951). The court held that the jury might have looked to the indictment to ascertain the acts committed by GMI pursuant to the conspiracy; that this was error, since the indictment charged a number of coercive acts, proof of no particular one of which was essential to a finding of guilt. 181 F.2d 70, 76-77. The court also held error the exclusion of certain GII evidence, id. at 78-83, and the award based on speculative nature of the amount of damages, $i d$. at $83-4$.

22. "And we think the judgment is available at least for the limited purpose of establishing that there had been a violation of public rights. . . . Hence we approve the ruling of the District Court-. . . all that was intended by Section 16, 15 U.S.C.A., was that plaintiffs in cases of this nature were to be accorded the advantage of establishing a prima facie case of conspiracy to violate the anti-trust laws by merely introducing the judgment of conviction in the criminal case.' "Id. at 75-76. "The Court of Appeals construes the section still more narrowly, holding the judgment prims facie evidence only of conspiracy by respondents." 340 U.S. 558, 567 (1951) (emphasis added).

23. While it is impossible to determine the particular coercive acts found, since the government did not have to prove all the acts charged, doubtless at least one of these acts had to be found by the jury. See note 20 supra. Thus, the judgment scems to establish coercion as well as conspiracy. The Seventh Circuit apparently agreed with this view in affirming the criminal conviction, although in the treble damage suit it restriets the prima facie effect of the judgment to the fact of conspiracy. See ibid.

24. 340 U.S. 558,570 (1951).

25. "We are, therefore, of opinion that the criminal judgment was prima facie evidence of the general conspiracy for the purpose of monopolizing the financing of General Miotors cars, and also of its effectuation by coercing General Motors dealers to use GIIAC." Id. at 570-71.

26. "In summary the trial judge should (1) examine the record of the antecedent case to determine the isstes decided by the judgment; (2) in his instructions to the jury reconstruct that case in the manner and to the extent he deems necessary to acquaint the jury fully with the issues determined therein; and (3) explain the scope and effect of the former judgment on the case at trial." Id. at 572 (emphasis added). 
Act and particular means used to effectuate that purpose are, as a matter of practice, essential to a finding of guilt, trial judges are free to extend the prima facie scope of criminal judgments under Section 5 to include these activities. In the Emich opinion, for example, the Supreme Court regarded the prior criminal judgment as prima facie evidence of illegal coercion as well as conspiracy. ${ }^{27} \mathrm{~A}$ treble damage plaintiff may thus be saved establishing by independent evidence defendant's coercive conduct towards, for example, other franchised dealers. ${ }^{28}$ In this way, proof of the causal link between the conspiracy and his injury by consequent coercive acts can be eased.

But even under the Emich decision, Section 5 will be of limited utility to treble damage plaintiffs. Many government proceedings are terminated by pleas of nolo contendere or consent decrees. ${ }^{20}$ Since both of these are exempt from the application of Section 5,30 fewer prior judgments or decrees are avatilable to private suitors. And only plaintiffs injured by the illegal activity upon which the judgments or decrees are based can utilize for Section 5 purposes the prior government litigation. Moreover, potential plaintiffs will often be unwilling to stand by for many years until the government litigation has terminated in final judgment or decree as required by Section 5.31 And

27. See note 25 supra.

28. Emich, in the trial court, introduced independent evidence of effectuntion of the conspiracy by coercion on dealers to use GMAC. See Amicus Brief for the United States, p. 38 n. 28, Emich Motors Corp. v. General Motors Corp., 340 U.S. 558 (1951).

29. Consent decrees, first used in 1906, have been entered in more than 50 percent of the equity proceedings brought by the government between 1906 and July 1,1050 (280 decrees in 551 cases). "This percentage is even larger if only cases filed within the last 10 years are considered." Antitrust Laze Enforcement by the Fcderal Trade Commission and the Antitrust Division, Department of Justice, H.R. REp. No. 3236, 81st Cong., 2d Sess. 66 (1951). There has also been an increase in the number of criminal prosecutions terminated by pleas of nolo contendere. For general discussion see testimony of Herbert A. Bergson, former Assistant Attorney General in charge of Antitrust Division, Department of Justice, Hearings on H.R. 6987 , supra note 2 , pt. 3 , pp. 46.8 (1950).

30. The exemption in $\S 5$, stupra note 11 , of "consent judgment or decrees" has been interpreted to include judgments rendered in criminal prosecutions on pleas of nolo contendere and consent decrees entered in civil proceedings prior to the introduction of testimony. Twin Ports Oil Co. v. Pure Oil Co., 26 F. Supp. 366, 370-9 (D. Minn. 1939), aff'd, 119 F. 2d 747 (8th Cir. 1941), cert. denied, 314 U.S. 644 (1941). See Dix, Decrces and Judgments under Section 5 of the Clayton Antitrust Law, 30 GEo. L.J. 331 (1942). These exemptions were designed to save the government time and expense of litigation by inducing defendants to settle with the government without litigation. H.R.REr. No. 627, 63d Cong., 2d Sess., pt. 2, 9 (1914); Dix, supra at 344. It is difficult to estimate the extent to which the exemption from $\S 5$ is responsible for recent increases in consent decrees, since there are other pressures, such as minimization of litigation costs, on defendants to avoid litigation with the government. For general discussion of reasons motivating defendants to enter consent decrees, see Isenbergh \& Rubin, Antitrust Enforccment Through Consent Decrees, 53 Harv. L. Rev. 386, 387 (1940) ; L.G's Page: Numerous Antitrust Suits, Financial World, Jan. 9, 1952, p. 12.

31. See Hearings on H.R. 7905, supra note 2, pt. 5, pp. 3, 5 (1950). For discussion of what constitutes a "final judgment or decree" within the meaning of $\S 5$ see notes 12 and 
most important, prior judgments and decrees are only prima facie evidence of issues previously determined, and can be overcome by contrary evidence introduced by the defendant. ${ }^{32}$ Thus, in practice, a treble damage plaintifi cannot rely on Section 5 but must relitigate much of the government's case. 33

To preclude wasteful relitigation and strengthen antitrust enforcement, Congress should amend Section 5 by making its evidentiary effects conclusive. $^{34}$ Accordingly, prior adjudication would establish conclusively the treble damage defendant's violation of antitrust law ${ }^{35}$ and all other essential issues previously determined. An amended Section 5 would encourage private litigants and bolster the treble damage suit as an antitrust sanction. ${ }^{36}$ More-

16 supra. The statute of limitations is suspended for private suitors when government institutes proceedings against defendant. 38 ST.1T. 731 (1914), 15 U.S.C. 16 (1946). Since Congress failed to provide a federal statute of limitations, state statutes apply. For "patchwork of disparate time limitation in antitrust cases" see Note, 60 Y.MLE L. J. 553 (1951).

32. See note 14 supra.

33. "Section 5 , in and of itself, means little to a plaintiff unless he fortifies its impact upon the minds of the jury with a dramatic reproduction, de nowo, of the same lind of evidence which resulted in the Government's earlier victory. . . . Section 5 substantially decreases neither the length of treble damage suits, the extent of trial preparation nor the cost ..." Communication to YALE LAW Jounnal from Harold Stidier, attorney for plaintiff in the Emich Case, dated May 17, 1951, in Yale Law Library. "As a practical matter the use of a criminal judgment to prove the existence of a public conspiracy is of very little value. ... [It is] usually desirable to introduce proof of the public conspiracy outside of the criminal judgment . . ." Communication to YALE LAw Jounual from Ferris E. Hurd, attorney for defendant in Emich Case, dated May 28, 1951, in Yale Law Library. See also Fearings an H.R. 7905, supra note 2, pt. 5, pp. 4, 13 (1950).

34. Section 5 of the original house bill provided for a cunclusive presumptiun. H.R. REP. No. 627, 63rd Cong., 2d Sess. 2 (1914). The Senate substituted a prima facie presumption because it feared that a conclusive presumption would deny due process to treble damage defendants by depriving them of their day in court. S. REP. No. 698, 63d Cong., 2d Sess., 45, 48 (1914). A Congressional committee recently considered maling \$ 5 's effect conclusive in connection with the Denton Bill. Hearings on H.R. $\% 905$, supra note 2 , pt. 5. But this proposal was absent in the bill as reported out of committee.

35. "The initial problem merely of proving... [the antitrust violation] is one which few persons can afford to undertake." Donovan \& Irvine, Proof of Damages Under The Anti-Trust Law, \&8 U. of PA. L. Rev. 511, 525 (1940).

36. Treble damage actions have great potential as antitrust sanctions, since they threaten antitrust violators with severe financial penalties. E.g. Kiefer-Stewart Co. v. Joseph E. Seagram \& Sons, Inc, 340 U.S. 211 (1951), reversing 182 F.2d 228 (7th Cir. 1950) (trebled damages totaled $\$ 975,000$ and the amount of attorney's fees was $\$ 50,000)$. For recent increase in treble damage suits, see note 3 supra. For discussion of effect of this increase on public antitrust enforcement, see testimony of $\mathrm{H}$. Graham Morison, Assistant Attorney General in Charge of the Antitrust Division, Department of Justice: "[W]e have for the first time since the history of the enactment of the Clay"ton Act and the Sherman Antitrust Act, begun to see the development of private litigation under the triple-damage statute, which is of substantial help. . . It is a substantial deterrent in whatever area the Government has decrees, and the effectiveness of this is for the first time being felt. We begin to feel that we have some companion clement of assistance in this which we never had before" Hcarings on $H . R$. 3108, supra note 2 , pt. 3, p. 15 (1951). 
over, conclusive evidentiary effect would lead to more antitrust settlements. since Section 5 does not apply to defendants' pleas of nolo contendere and consent decrees. More effective enforcement by the Antitrust Division would result. ${ }^{37}$ And conclusive evidentiary effects in later treble damage suits would not deny a day in court to antitrust defendants litigating with the government. ${ }^{38}$ Faced with adverse publicity ${ }^{30}$ and drastic decrees ${ }^{40}$ in government civil proceedings, sometimes also brought on the heels of criminal conviction, ${ }^{\mathbf{4 1}}$ antitrust defendants doubtless litigate fully any issues which subsequently might be held conclusive against them.

37. See testimony of Herbert A. Bergson, former Assistant Attorney General in Charge of Antitrust Division, Department of Justice, Hearings on H.R. 6987, supra noto 2, pt. 3, pp. $46-7$ (1950).

38. Cf. expansion of collateral estoppel to bar a plaintiff in a subsequent suit when raised by a defendant who was neither party nor privy to the prior litigation. CocrCola Co. v. Pepsi-Cola Co., 36 Del. 124, 172 Atl. 260 (1934) (issues decided against Coca-Cola in prior suit against Loft, Inc. held conclusive in favor of defendant PepsiCola in a subsequent suit brought by Coca-Cola against it) ; noted 82 U. oF PA. L. REv، 871 (1934). See also Cox, Res Judicata: Who Entitled to Plead, 9 VA. L. REv. 241 (1923). For expansion of estoppel in similar manner by extension of the concept of privity, sec Taylor v. Sartorious, 130 Mo. App. 23, 40, 108 S.W. 1089, 1094 (1908). However, collateral estoppel apparently has been expanded only as a defensive tool and not as a weapon of offense. See discussion in dissent, Finlay Elder v. New York \& Pennsylvania Motor Express, Inc., 284 N.Y. 350, 357, 31 N.E. 2d 188, 192 (1940). The major objection to any expansion of collateral estoppel is that it forces a party in the prior suit to litigate to the utmost regardless of the value to him of that particular litigation, since the results of the litigation may later estop him in a controversy with another adversary who had no connection with the first suit and when more is at stake. See Van Moschzisker, Res Judicala, 38 YaLE L.J. 299, 303 (1928). This objection has little merit in antitrust litigation.

39. For attempt to counter unfavorable publicity see discussion of A \& P's press campaign, Sufrin \& Harriman, Reflections on the $A$ \& $P$ Case, 2 SYR. L. REv, 26, 35-6 (1950).

40. E.g. United States v. Pullman Co., 53 F. Supp. 908 (E.D. Pa. 1944) (scparation of manufacture and operation of sleeping cars). But cf. United States v. Aluminum Co. of America, 91 F. Supp. 333 (S.D. N.Y. 1950) (fabricating plants and ingot production not separated). See Comment, 60 Y ALE L.J. 294 (1951).

41. The Antitrust Department sometimes follows criminal prosecutions, in which evidence is garnered by grand juries, with civil suits against the same defendants. $E, g$. criminal conviction of A \& P for conspiracy to restrain and monopolize trade in food industry, United States v. The New York Great Atlantic \& Pacific Tea Co., 67 F. Supp. 626 (E.D. Ill. 1946), aff'd, 173 F. 2 d 79 (7th Cir. 1949), followed by civil complaint seeking to (1) separate A \& P's manufacturing and processing business from buying and selling business, (2) separate retail division into independently owned chains, and (3) dissolve wholesale purchasing and sales agent for produce. Civil No. 52,139 (S.D. N.Y. 1949) CCH Trade Reg. Rep. '48-'51 Dec. $\llbracket 61,226$. 